\title{
Teaching Against Extremist Ideologies Through Evidence Obtained from the Holy Quran
}

\author{
Sonya Talat Ibrahim Al-Shami* Prof. Mohammad Amin Al-Qudah \\ Faculty of Education, The University of Jordan, Amman, Jordan
}

\begin{abstract}
Without proper religious education, the Muslim youth continue to be targeted for destructive, deviant and straying ideas by terrorist groups that may lead to extreme ideologies far from the moderate nature of Islam, and therefore the consequences may be disastrous and could lead to acts of terrorism. The absence of the true understanding of Islamic teaching leaves a catastrophic impact on the Islamic nation and the world; hence it is worth noting that learning how to counter these deviated ideologies through evidence obtained from Quranic texts is crucial to eliminate the ongoing threats, as this knowledge responds to falsehood, refutes it, and invalidates it. The religious information given in conventional education is insufficient for Muslim students to face the growing challenges in the environment around them, especially in an era where there is a lot of confusion, distortion of facts, intolerance, and intellectual and behavioral extremism. Therefore, this study calls for the reconsideration of the role of educational institutions, and to transfer conventional education from indoctrination, memorization, and recitation, to teaching students thinking skills. There are many examples in Quran that show how to use the rational approach and critical thinking in order to remove false ideas. It is crucial to develop educational curricula and teaching methods by adding the method of mental and logical reasoning based on evidence obtained from Quran in order to emphasize Islamic principles of justice, tolerance, security and coexistence
\end{abstract}

Keywords: Education, Extremism, Quran, Thinking Skills.

DOI: $10.7176 / \mathrm{JEP} / 11-13-13$

Publication date:May $31^{\text {st }} 2020$

\section{Introduction}

God Almighty sent apostles and prophets whose efforts were focused on promoting good deeds, purifying humans from evil, and correcting the wrongs that had been committed (Hamada, 2012). This was most evident in the message of Prophet Muhammad, peace and blessings be upon him. The effect of Islam on the Arabs is evident as they have transformed from rival tribes into brothers in Islam enjoying security and faith, and that was only fulfilled through Islamic education that cultivates intellectual maturity and behavioral responsibility, God says in the Holy Quran: (And remember the favor of Allah upon you - when you were enemies and He brought your hearts together and you became, by His favor, brothers. And you were on the edge of a pit of the Fire, and He saved you from it. Thus does Allah make clear to you His verses that you may be guided) Chapter (Ch.) 3, verse (V.) 103.

The mind is the basis of accountability in Islam, and with it one can know right from wrong. Knowledge cannot be acquired without reason; therefore, reason is considered a virtue and an honor. It is through reason that people may experience happiness in this world and the hereafter, so if a person thinks rationally, he will not go astray. On the other hand, if one's reasoning is affected by hatred and bigotry, his reasoning will surely be obscured and diverted. In this case, man will suffer both in this world and the Hereafter, as his life would be filled with misery, and he will receive the punishment of God Almighty in the Hereafter for violating his orders. God says: (And the Messenger has said, "O my Lord, indeed my people have taken this Quran as [a thing] abandoned.") Ch. 25, V. 30, if one abandons the contemplation and true understanding of the Quran, it is as if he has abandoned the Quran all together. The Holy Quran is a book of reason, thus a mind full of delusion and arrogance cannot reach the truth (Hamad, 2014).

Islam urges people to use their rationale. Unlike the prophets and messengers before him, Prophet Muhammad, peace and blessings be upon him, presented lots of rational evidence of his prophethood through the Quran. God Almighty revealed: (But they say, "Why are not signs sent down to him from his Lord?" Say, "The signs are only with Allah, and I am only a clear warner. And is it not sufficient for them that We revealed to you the Book which is recited to them? Indeed in that is a mercy and reminder for a people who believe.) Ch. 29, V. 50-51.

The Holy Quran is God's concluding message to all people, as it is the speech of God Almighty which is undoubtedly guidance for people. God Almighty says: (Invite to the way of your Lord with wisdom and good instruction, and argue with them in a way that is best. Indeed, your Lord is most knowing of who has strayed from His way, and He is most knowing of who is [rightly] guided) Ch. 16, V. 125.

The Holy Quran urges participation in dialogue in a manner that reflects the morals of the Muslims and the tolerance of Islam, with the aim of reaching the truth and guiding creation. According to the previous verse, the best way for dialogue that the Quran urges is with "wisdom and good instruction", and argumentation should be "in a way that is best", meaning the establishment of rational arguments provided with evidence.

Every believer is required to learn how to defend his beliefs by stating arguments based on evidence, or else 
he would be prone to surrender to those who invite him to another belief system. Thus, the Quran has declared that there is no claim without evidence: (Say: "Give your proof, if you are truthful"), Ch. 2, V. 111 (Al-Qaradhawi, 2009).

The approach of the majority of Sunni Muslims is not limited to preaching, but rather understanding matters of belief, explaining religious text, directing the behavioral and moral aspects, and assuring reform and change. The challenges and problems facing the Islamic nation today have increased, which go beyond intellectual moderation to both extremism and negligence. Moderation is required in all aspects of the learner's personality, as it is not limited to avoiding extremism and negligence, but it is a characteristic that the Islamic approach seeks to achieve within the learner, whether it be his interests, his way of thinking, his vision for reform, or his social, psychological, cultural and educational life (Al-Murabbi Institute, 2011).

Therefore, it has become necessary for educators to reconsider the role of educational institutions, and the role of teachers, and to transfer the conventional education from indoctrination, memorization, and recitation, to teaching students thinking skills and heading toward critical thinking. The religious information given in conventional education is insufficient for Muslim students to face the growing challenges in the environment around them, especially in an era where there is a lot of confusion, distortion of facts, intolerance, and intellectual and behavioral extremism. The primary goal of teaching students critical thinking skills is to enable them to succeed in various aspects of life by abiding to Islamic moderation (Al-Jabri and Al-Amri, 2013).

This is because the Holy Quran is filled with many examples that show the educator how to use the rational approach and critical thinking in discussion and dialogue in order to remove false ideas, and plant honest ideas depicting the truth. Among these examples is the establishment of logical evidence. Hence, it is imperative for the Muslim mind to continuously undergo contemplation, insight, reflection, understanding, and so on, as the Quran urges (Ali, 2007).

The blessing of security is considered one of the greatest blessings that God has bestowed upon His servants, and a necessary requirement of human life. Therefore, one of the purposes of the Islamic law was to preserve the five essentials: life, religion, mind, progeny, and property. Security is a state in which the individual and society feel reassured about their lives, beliefs, culture, and customs, and feel protected against distortion, confusion, and hostility. As for extremism, it is so dangerous that not only simple and naive people fall prey to it, but also educated people may be fooled by it as well, affected by deception, distortion of facts, and reversal of concepts. This results in conflict and a tendency to argue and dispute, which in turn may result in inconsistency, hostility, revenge, and justification of ends in a way that might threaten National Security (Promising Research Center for Social and Women's Studies, 2016).

Those who are intellectually and behaviorally delinquent divide and interpret the Quranic verses according to their whims and in a way that serves their interests and deviant thoughts, so that they take the texts out of context and move away from the tolerant moderation that characterizes Islam (Al-Lwaihiq, 2010). As for the nature of the Quranic argument, it is dependent on the context and leaves no room for division. It responds to falsehood, refutes it, and invalidates it. God Almighty says: "Rather, we throw away the truth on falsehood, then it is overpowered, so what is it?" Ch. 21, V. 18.

\section{Research Problem}

The Islamic nation suffers at the present time from misrepresentation and failure to show the truth of religion in word and deed, and this is one of the reasons that has led to the emergence of extremism on the one hand and negligence on the other hand, thus showing various kinds of deviated and extremist ideologies (Odeh and AlSafadi, 2014). The scarcity of Muslim thinkers and educators who are good at understanding the mentality of extremists and responding to their claims in a logical way is considered one of the biggest and most harmful problems today. Consequently, it has become one of the most important necessities of this era to learn the basics of dialogue and debate based on reason and logic (Hanafi, 2015). This science is found in the Holy Quran and the Noble Prophet's Sunnah and needs further study, analysis, and application using the latest educational means.

The study of evidence obtained from Quran will undoubtedly help in expanding one's mind and thinking skills, and help Muslims elevate their faith and tolerance of others. It also helps in developing educational curricula and teaching methods by adding the method of mental and logical reasoning based on evidence obtained from Quran.

\section{Research Objectives}

This study aims at examining evidence from the Holy Quran which yield a better understanding of the persuasive discourse in Quran, which in turn sets the nature of the relationship of Muslims among themselves, and between Muslims and Non-Muslims according to Islamic principles of justice, tolerance, security and coexistence.

\section{Research Importance}

4.1 The importance of this study emerges from the following:

4.1.1 Teaching children evidence derived from the Holy Quran is one of the most successful methods of raising 
children on the correct understanding of the Islamic religion. It also gives Muslims the skill and confidence to participate in dialogues.

4.1.2 To address the problem of distorting perceptions and reversing the facts to which Islam is exposed in our time, a basis should be built for Muslims, whether individuals, groups or institutions, to engage in organized dialogues based on logic, in order to respond to the slanders and accusations that are being made against Islam and its symbols and sanctities.

4.1.3 An indispensable educational necessity is learning critical thinking skills, based on contemplation, analysis, discussion, comparison, reasoning, contemplative skepticism, identifying contradictions, awareness of the context, checking the results, and deduction. This requires accuracy and adopting logical criteria in assessing beliefs. This can only be achieved through practice and training, hence the importance of understanding and teaching evidence in the Quran, which in turn urges reflection and logical thinking.

4.2 It is also hoped that the following authorities will benefit from the results of this study:

4.2.1 The Muslim youth who are targeted for destructive, deviant and straying ideas by terrorist groups that may lead to extremist ideologies far from the moderate nature of Islam, and therefore the consequences may be disastrous and could lead to acts of terrorism.

4.2.2 The teachers and advocates of Islam: by modernizing the religious discourse and helping students reach a full understanding of the Quran based on evidence that counters extremist ideologies.

\section{Research Definitions:}

This study adopts the following terminology:

5.1 Holy Quran: is the Holy Book for Muslims believed to be revealed by God Almighty to His Messenger, Muhammad, peace and blessings be upon him, and is recited and studied by all Muslims in the world as an act of worship.

5.2 Quranic Evidence: is evidence derived directly from Quranic text or obtained through the understanding of the text which is based on the exegesis of the Quran by certified, trustworthy and renowned scholars to prove a certain point, and is in full alignment with the context from which it is obtained and does not contradict the overall logic of the Quran.

5.3 Extremist Ideologies: The Center for Promising Research in Social and Women's Studies (2016) shows that the term extremist ideologies has a definition adopted by the State, which is "breaking the law and not abiding by its generally accepted rules and legislations." (p. 4) It also has a broader societal definition, which is "the deviation of ideas and concepts from all agreed standards, values and beliefs prevailing in society." (p. 4) Al-Azhar, who is mentioned in Al-Juhani (2008) says that extremist ideologies "may be in thought alone if behavior is not affected by it, and it may be in behavior alone without premeditated thought, and it may affect both thought and behavior. It may also be just an opinion, and it may be a doctrine when it is believed whole-heartedly and felt on an emotional level, in which case its extraction needs a stronger argument and a more intense treatment." (p. 63)

\section{Research Methodology:}

We have recently witnessed many movements that falsely use Islam as an excuse to pass their extremist ideologies, which challenges the nation's body and mislead its youth. This behavior allows these people to resort to violence and shed innocent blood.

From the foregoing it becomes clear that the absence of the true understanding of Islamic teaching leaves a catastrophic impact on the nation and the world, hence it is worth noting that learning how to counter these deviated ideologies through evidence obtained from the Quranic texts is crucial to eliminate the ongoing threats.

6.1 Extremist Ideologies may be manifested through the following (Promising Research Center for Social and Women's Studies, 2016):

6.1.1 Misleading and deceiving people.

6.1.2 Distorting facts and deviating concepts.

6.1.3 Theological, ideological and emotional conflict marked by the tendency to assault and revenge.

6.1.4 Rudeness and roughness in dialogue.

6.1.5 Extremism and imposing opinion on others by all means.

6.1.6 Acts of Terrorism, which has been defined by the Council of the Islamic Jurisprudence Academy of the Organization of the Islamic Conference as "aggression by individuals, groups, or states that is a tyranny against a person (his life, religion, mind, progeny, and property) and includes the types of intimidation, harm, threat, unlawful killing and every act of violence or threat, carried out in implementation of an individual or collective criminal project that aims to intimidate people by harming them, or endangering their lives, freedom, and security"(Al-Lwaihiq, 2004, P. 118).

6.2 The Causes of Extremist Ideologies according to the (Promising Research Center for Social and Women's Studies, 2016) and (Al-Bawwab, 2011) are:

6.2.1 Ignorance of aspects of creed, jurisprudence, and shortcomings in the application of Sharia. 
6.2.2 Extremism in understanding and application of religion.

6.2.3 Shallow understanding of religious texts without knowing their true meaning.

6.2.4 Seeking discord and an interpretation of the Quranic texts that is suitable to them.

6.2.5 Extracting verses from the Quranic texts without taking the context into consideration.

6.2.6 Poor socialization.

6.2.7 Deficiencies in aspects of education and its institutions.

\section{Intellectual Security}

Intellectual Security can be defined by the government and society in terms of sparing individuals and groups the ideological, intellectual and psychological impurities that cause the deviation of thought and behavior through the activities and measures taken by the government (Naser, 2003). It can also be defined based on the individual, as Al-Rahili (2016) indicated that intellectual security includes the concepts of immunity and moderation. As for moderation, it is in understanding all aspects of religious, intellectual, social, cultural and political life through Islamic principles and values represented in the Holy Quran and the Noble Prophet's Sunnah, which leads to discipline of the individual's behavior and thought and achieving security, tranquility and stability in all aspects of life (Al-Rahili, 2016).

In short, intellectual security is achieved through the elimination of deviated thoughts and extremist ideologies, whether by educational modifications based on teaching moderation and acceptance of others, or by security measures taken by the State.

\section{Quranic Evidence against Extremist Ideologies}

Quran teaches Muslims the principles of moderation in all aspects of life. It promotes peaceful mentality which is a protection against all forms of extremism. In this study it will be sufficient to mention only eight examples of how the Holy Quran calls for intellectual security and teaches against extremist ideologies.

8.1 Evidence of how the Quran teaches against extremist ideologies:

8.1.1 Imitation and Tradition:

God Almighty reveals in Quran how nations have fought against revelation from early on by holding on to that which they have found their forefathers believing and worshiping. God says: (Rather, they say, "Indeed, we found our fathers upon a religion, and we are in their footsteps [rightly] guided." * And similarly, We did not send before you any warner into a city except that its affluent said, "Indeed, we found our fathers upon a religion, and we are, in their footsteps, following." * [Each warner] said, "Even if I brought you better guidance than that [religion] upon which you found your fathers?" They said, "Indeed we, in that with which you were sent, are disbelievers." * So we took retribution from them; then see how was the end of the deniers.) Ch. 43, V. 22-25. The word "warner" in these verses refers to the prophets and messengers who warned their people against following the beliefs of their "fathers", meaning forefathers and authority figures, whether it may be religious leaders or politicians and the like, whose preaching people follow without question or thought. This kind of imitation and following tradition without contemplation can be catastrophic. God also says in another verse: (And when it is said to them, "Follow what Allah has revealed," they say, "Rather, we will follow that which we found our fathers doing." Even though their fathers understood nothing, nor were they guided?) Ch. 2, V. 170, and in other verses, God explains how this has been going on since the beginning of time: (O children of Adam, let not Satan tempt you as he removed your parents from Paradise, stripping them of their clothing to show them their private parts. Indeed, he sees you, he and his tribe, from where you do not see them. Indeed, We have made the devils allies to those who do not believe. * And when they commit an immorality, they say, "We found our fathers doing it, and Allah has ordered us to do it." Say, "Indeed, Allah does not order immorality. Do you say about Allah that which you do not know?") Ch. 7 V. 27-28. This clearly states how Quran warns against following the teachings and traditions of anyone without proper education and guidance. Humans don't easily accept an open invitation to wickedness, but Satan has a way of deceiving and beautifying the wrong deeds by giving tangible justifications that the human mind can agree with, if not given enough thought. This also applies to modern day groups who call for extreme ideologies without true evidence from the Holy Quran and Noble Sunnah. Following such groups can be disastrous.

8.1.2 Bigotry and Intolerance:

Bigotry comes in all forms, whether hateful speech, chauvinism, bias, prejudice, racism, arrogance, etc. God draws a picture of one form of bigotry in the following verses: (When those who disbelieved had put into their hearts chauvinism - the chauvinism of the time of ignorance. But Allah sent down His tranquility upon His Messenger and upon the believers and imposed upon them the word of righteousness, and they were more deserving of it and worthy of it. And ever is Allah, of all things, Knowing.) Ch. 48 V. 26. In this verse, God declares that chauvinism is an act of ignorance, as it denies the person from thinking straight and making good decisions. So do other forms of bigotry, such as it is explained in the following story: (And We had certainly sent Noah to his people, [saying], "Indeed, I am to you a clear warner * That you not worship except Allah. Indeed, I fear for you the punishment of a painful day." * So the eminent among those who disbelieved from his people said, "We do not see you but as a 
man like ourselves, and we do not see you followed except by those who are the lowest of us [and] at first suggestion. And we do not see in you over us any merit; rather, we think you are liars." * He said, "O my people have you considered: if I should be upon clear evidence from my Lord while He has given me mercy from Himself but it has been made unapparent to you, should we force it upon you while you are averse to it? * And O my people, I ask not of you for it any wealth. My reward is not but from Allah. And I am not one to drive away those who have believed. Indeed, they will meet their Lord, but I see that you are a people behaving ignorantly. * And O my people, who would protect me from Allah if I drove them away? Then will you not be reminded? * And I do not tell you that I have the depositories [containing the provision] of Allah or that I know the unseen, nor do I tell you that I am an angel, nor do I say of those upon whom your eyes look down that Allah will never grant them any good. Allah is most knowing of what is within their souls. Indeed, I would then be among the wrongdoers." * They said, "O Noah, you have disputed us and been frequent in dispute of us. So bring us what you threaten us, if you should be of the truthful." * He said, "Allah will only bring it to you if He wills, and you will not cause [Him] failure.) Ch. 11 V. 22-33. God sent His messenger, Noah, peace be upon him, to people of his time to guide them, but their ignorance was evident as they looked down upon those who followed Noah because they were poor and weak. They described them as "those who are the lowest of us", and they did not believe Noah since he did not have any materialistic or positional merit over them, and so were his followers. This was the criteria by which those people weighed the worth of a person. And this kind of arrogance creates bigotry that overwhelms a person and denies him of seeing the truth and doing the right thing. Therefore, by setting these examples, the Holy Quran teaches against such hatred.

8.1.3 Ignorance:

God Almighty describes people who do not give effort to think and reflect upon the teachings of the Holy Quran as ignorant, and He tells His Messenger, Muhammad, peace be upon him, to turn away from the ignorant who insist on staying away from true guidance: (And if you invite them to guidance, they do not hear; and you see them looking at you while they do not see. * Take what is given freely, enjoin what is good, and turn away from the ignorant.) Ch. 7, V. 198-199. God also describes the righteous by the virtue of humbleness and peaceful thinking, He says: (And the servants of the Most Merciful are those who walk upon the earth easily, and when the ignorant address them [harshly], they say [words of] peace,) Ch. 25, V. 63. And in another verse He says: (And when they hear ill speech, they turn away from it and say, "For us are our deeds, and for you are your deeds. Peace will be upon you; we seek not the ignorant.") Ch. 28, V. 55. These examples clearly show how Quran teaches against ignorance which usually leads to disputes and acts of violence. Only the righteous are those who seek peace.

8.1.4 Atheism:

Just as deviation in religiousness may lead to ignorance, bigotry and extremism, so does atheism. The non-believers may also develop a sense of hatred toward religious people and that in turn may lead to extreme thoughts and acts of violence. There are so many verses in the Quran in which God addresses the non-believers and calls for paying attention to the universe and give thought to creation. For example God says: (And he presents for Us an example and forgets his [own] creation. He says, "Who will give life to bones while they are disintegrated?" * Say, "He will give them life who produced them the first time; and He is, of all creation, Knowing." * [It is] He who made for you from the green tree, fire, and then from it you ignite. * Is not He who created the heavens and the earth Able to create the likes of them? Yes, [it is so]; and He is the Knowing Creator.) Ch. 36 V. 78-79. In these verses God gives us an example of a man who does not believe in the Hereafter because he does not believe in God in the first place. This ignorance reflects on this man's life, as he will not be fearful of any wrong-doing since he does not believe that there is a Day of Judgment. This kind of person is dangerous and may cause lots of harm to mankind, especially to those who do believe. This also is a form of extremism that the Qurans warns against.

8.2 Evidence of how the Quran teaches Muslims to abide by intellectual security:

8.2.1 Tolerance and Freedom of Belief:

Quran calls for freedom of belief. God says: (And say, "The truth is from your Lord, so whoever wills - let him believe; and whoever wills - let him disbelieve.") Ch. 18, V. 29. And this freedom also applies when inviting people of other religions to Islam. God says: (There shall be no compulsion in [acceptance of] the religion. The right course has become clear from the wrong.) Ch. 2, V. 256. This is clearly stated in the next verse where God addresses His Messenger, Muhammad, peace be upon him, and explains to him how he should deal with people who do not believe in the message of Islam. God says: (And if they deny you, [O Muhammad], then say, "For me are my deeds, and for you are your deeds. You are disassociated from what I do, and I am disassociated from what you do.") Ch. 10, V. 41. This kind of tolerance and acceptance of others is proof that Islam does not force others to be Muslims nor should Muslims fight or harm others in order to force them to be Muslims. Each person is held accountable in front of God, who alone will determine the destiny of all people. Quran also mentions the ethics of dialogue, explaining that one should always give others the benefit of doubt when talking to those with whom he may disagree, even in religion. God says: (Say, "Who provides for you from the heavens and the earth?" Say, "Allah. And indeed, we or you are either upon guidance or in clear error." * Say, "You will not be asked about what we committed, and we will not be asked about what you do.") Ch. 34, V. 24-25. 


\subsubsection{Moderation:}

God Almighty says in the Holy Quran: (And thus we have made you a just community that you will be witnesses over the people and the Messenger will be a witness over you.) Ch. 2, V. 143. The word "Just" in this verse is a rough translation from the Arabic word "wasata" which literally means "in the middle". The Pakistani scholar, Abul Ala Maududi (1988), explains this verse by saying: "The Arabic expression which we have translated as 'the community of the middle way' is too rich in meaning to find an adequate equivalent in any other language. It signifies that distinguished group of people which follows the path of justice and equity, of balance and moderation, a group which occupies a central position among the nations of the world so that its friendship with all is based on righteousness and justice and none receives its support in wrong and injustice." He goes on to explain that "this is at once a great honour and a heavy responsibility. For what it actually means is that just as the Prophet served as a living example of godliness and moral rectitude, of equity and fair play before the Muslim community, so is the Muslim community required to stand vis-a-vis the whole world. What is expected of this community is that it should be able to make known, both by word and deed, the meaning of godliness and righteousness, of equity and fairplay." (p. 116)

Islam calls for a balanced system of life, and it teaches moderation in every aspect of life. God says: (And [they are] those who, when they spend, do so not excessively or sparingly but are ever, between that, [justly] moderate) Ch. 25, V. 67. God also says: (O children of Adam, take your adornment at every masjid, and eat and drink, but be not excessive. Indeed, He likes not those who commit excess.) Ch. 7, V. 31. These are examples that excess is not a virtue in Islam, and therefore, religious extremism is also forbidden.

\subsubsection{Nurturing Thought:}

Throughout Quran you will find many examples on how one should nurture and develop his mentality, and how God will further educate people on the right way of thinking. For example God says: (O you who have believed, if you fear Allah, He will grant you a criterion and will remove from you your misdeeds and forgive you. And Allah is the possessor of great bounty.) Ch. 8, V. 29. This criterion which God will grant those who fear Him will allow them to know right from wrong, and educate them on how to deal with the rest of humanity.

But of course, not all people have a healthy mentality, even if on first impression one might think so. God warns against those who are deceitful, giving pleasant speeches and fooling people into believing their arguments, while their actions show otherwise. God says: (And of the people is he whose speech pleases you in worldly life, and he calls Allah to witness as to what is in his heart, yet he is the fiercest of opponents. * And when he goes away, he strives throughout the land to cause corruption therein and destroy crops and animals. And Allah does not like corruption. * And when it is said to him, "Fear Allah," pride in the sin takes hold of him. Sufficient for him is Hellfire, and how wretched is the resting place.) Ch. 2, V. 204-206. This example proves that it is by ones actions that we should judge. Those who seek to corrupt and perform acts of hostility and hatred are the ones who are far from the peace and moderation that Islam calls for.

In other verses we find examples on how the Quran educate us and cultivate our thinking skills, such as verses that compel us to form comparisons, like this one for example: (They ask you about wine and gambling. Say, "In them is great sin and [yet, some] benefit for people. But their sin is greater than their benefit.") Ch. 2, V. 219-220. 8.2.4 The Role of the State:

I explained above how it is the government's duty to spare individuals and groups the ideological, intellectual and psychological impurities that cause the deviation of thought and behavior through some of the activities and measures taken. God declares in Quran that it is the duty of the State to incline to peace and spread security to all individuals. God says: (And if they incline to peace, then incline to it [also] and rely upon Allah. Indeed, it is He who is the Hearing, the Knowing.) Ch. 8, V. 61.

But, in case the State has been attacked then in is obligatory for the government to refer to defense and fight back. However, it is clearly declared more than once that fighting the transgressors should not turn the defenders into transgressors. When the enemy requests cease of fire then Muslims should abide and cease as well. God says: (Fight in the way of Allah those who fight you but do not transgress. Indeed. Allah does not like transgressors. * And kill them wherever you overtake them and expel them from wherever they have expelled you, and fitnah is worse than killing. And do not fight them at al-Masjid al- Haram until they fight you there. But if they fight you, then kill them. Such is the recompense of the disbelievers. * And if they cease, then indeed, Allah is Forgiving and Merciful. * Fight them until there is no [more] fitnah and [until] worship is [acknowledged to be] for Allah. But if they cease, then there is to be no aggression except against the oppressors. * [Fighting in] the sacred month is for [aggression committed in] the sacred month, and for [all] violations is legal retribution. So whoever has assaulted you, then assault him in the same way that he has assaulted you. And fear Allah and know that Allah is with those who fear Him.) Ch. 2, V. 190-194.

It is also the role of the State to establish justice. God says: (O you who have believed, be persistently standing firm for Allah, witnesses in justice, and do not let the hatred of a people prevent you from being just. Be just; that is nearer to righteousness. And fear Allah; indeed, Allah is Acquainted with what you do.) Ch. 5, V. 8. God also says in another verse: (O you who have believed, be persistently standing firm in justice, witnesses for Allah, even 
if it be against yourselves or parents and relatives. Whether one is rich or poor, Allah is more worthy of both. So follow not [personal] inclination, lest you not be just. And if you distort [your testimony] or refuse [to give it], then indeed Allah is ever, with what you do, Acquainted.) Ch. 4, V. 135. Therefore, a just State will not witness any tyranny or transgression or be tolerant of bigotry and hostility toward any minority or individual.

\section{Conclusion}

From the aforementioned, it is clear that Quran calls for the implementation of intellectual security to all people, and fights extremist ideologies and behaviors. From this knowledge, I conclude that it is obligatory to teach students from early on the evidence declared in Quran that teaches against extremism and terrorism. The current educational system in most of the Islamic world depends on indoctrination and memorization of Quran instead of the true understanding of its meaning and lessons. Therefore, it is essential to make radical changes to the curricula and the ways and means of teaching Quran, and integrate the understanding of scholars of exegesis with the psychological study of critical thinking and other thinking skills. With this integration, Quranic texts will be wellunderstood and well-implemented by the youth. Extremists will not be able to deceive and delude, and terrorist organizations will not be able to recruit. With the true understanding of Quran through studying evidence derived from it Muslims will expand their mentalities and elevate their faith, moderation, and tolerance of others. They will also be able to fight off distorted conceptions by giving evidence from Quran and Sunnah while remaining respectful of the ethics of dialogue.

\section{References}

Al-Balushi, F. M. A., and Al-Qudah, M. A. H. (2019), The Omani Electronic Media Address of the Intellectual Security: An Analytical Study of the Electronic Media Content Research, International Journal of Advanced Science and Technology, 13(4):240-253.

Al-Bawwab, J. Y. (2011), The Terrorism Phenomenon, Issues of The Era, 15(40):223-240.

Ali, S. I (2007), The Foundations of Islamic Education, $2^{\text {nd }}$ edn., Cairo: Dar Al-Salam Publication and Printing House.

Al-Jabri, K. K, and Al-Amri, M. M. (2013), Thinking: An Explanatory Psychological Study, Amman: Dar AlShurouq Publication and Distribution House.

Al-Juhani, A.B. F (2008), Intellectual Extremism and Society's Responsibility, Teachers Academy Journal, King Khaled University, Abha, KSA, (12): 57-91.

Al-Lwaihiq, A.R. B. M. (2004), Terrorism and Extremism: A Terminology Study, paper presented at The Scientific Record of The Position of Islam from Terrorism Conference, (1), Riyadh: Imam Mohammad Bin Saud Islamic University, 92-133.

Al-Lwaihiq, A.R. B. M. (2010), Different Principles to Face Intellectual Extremism, conducted at the meeting of the Ministry of Interior, Cairo, 1-31.

Al-Murabbi Institue (2011). Growth: An Approach to Building the Islamic Personality from Breastfeeding Till Beyond The University, Riyadh: Al-Murabbi Institue.

Al-Qaradhawi, Y. (2009), Mind and Science in the Holy Quran, $4^{\text {th }}$ edn., Cairo: Wahbe Library.

Al-Rahili, N. B. R. D (2016), The Role of Islamic Upbringing in Achieving Intellectual Security, Arab Journal for Security Studies, 32(67):35-65.

Hamada, F. (2012), Building Humans and Society, Damascus: Dar Al-Qalam.

Hamad, O. K. M. (2014), Islam and Way's of Thinking, Cairo: Dar Al-Salam Publication and Distribution and Translation House.

Hanafi, I. A. A. (2015), Argumentation in Modern Religious Discourse, Paper presented at the Arab Heritage Conference, 1, Cairo, 157-171.

Maududi, S. A. A. (1988), Towards Understanding the Quran, Vol. 1, Trans. \& Ed. Ansari, Z. I., London: The Islamic Foundation.

Naser, M. A. (2003), Quran's Methodology in Argumentation (unpublished master's thesis), Al-Najah National University, Nablis, Palestine.

Odeh, A. I. R. and Al-Safadi, N. A. (2014), Argument's Role in the Strength of Islamic Discourse, Almanara Journal for Research and Study, 20(3):347-372.

Omar, A. M. (2008), Modern Arabic Dictionary, Cairo: Alam alkutub.

Promising Research Center for Social and Women's Studies, (2016), Achieving Intellectual Security, Princess Noura Bint Abdel-Rahman University, Riyadh: Ministry of Education.

Quran Saheeh International (2020), Trans. Assami, E., Bantley, A., Kennedy, M. developed by Zarrabi-Zadeh, Retrieved from: http://tanzil.net/\#trans/en.sahih/1:1

Rahamneh, K. F. A., and Al-Qudah, M., A. H. (2016), A Proposed Educational Vision for Activating the Role of the Jordanian Universities Students Families in Enhancing Students Intellectual Security from the Students Perspective, European Scientific Journal, 12(16):1857-7881. 